\title{
Placement of self-expandable metallic stents with a laryngeal mask and a fiberoptic flexible bronchoscope for obstructive tracheobronchial lesions
}

Shinichiro Okada, MD, Shotaro Ishimori, MD, Shunsuke Yamagata, MD, Shoichi Satoh, MD, Sadanori Yaegashi, MD, and Yoshiaki Tanaba, MD, Iwate, Japan

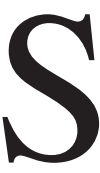

elf-expandable metallic stents have been used in the management of malignant or benign tumors causing airway stenosis or obstruction by means of a rigid bronchoscope or fluoroscopic control. ${ }^{1}$ However, fully trained personnel are needed to manage the rigid bronchoscope, and the sites to be reached with it are limited. Additionally, mandibular arthrosis, or limited mouth opening, or spinal deformities might present technical problems with the rigid bronchoscope. On the other hand, it might often be difficult to achieve the exact fitting of the stent under fluoroscopic control.

The laryngeal mask is a reusable device with a larger internal diameter, allowing easier passage of a fiberoptic flexible bronchoscope or instruments (Figure 1, A), and does not require the usual endotracheal intubation or mask ventilation..$^{2-5}$ In this report we describe a procedure of inserting a self-expandable metallic stent under direct visual control with the use of the new laryngeal mask and a fiberoptic flexible bronchoscope in the management of tracheobronchial obstructive lesions.

\section{Patients and Methods}

Stenting with a laryngeal mask and a flexible bronchoscope was performed after achievement of general anesthesia with a laryngeal mask placement (Figure 1, B). Placement of the laryngeal mask has been described elsewhere. ${ }^{5}$ Anesthesia was induced with propofol $(2.5-3.0 \mathrm{mg} / \mathrm{kg})$ and maintained with sevoflurane in $67 \%$ to $75 \%$ air. A muscle relaxant, such as vecuronium bromide, was used when necessary. Before stenting, bronchoscopic surgery, such as argon plasma coagulation or electrocautery, for airway lesions was performed when necessary. For stent insertion, we used a self-expandable metallic stent (Spiral Z stent; Medico's Hirata, Osaka, Japan). The flexible bronchoscope (BF P40; Olympus, Tokyo, Japan) was passed through the slit of the cap of the swivel connector (Portex Catheter Mount; SIMS Portex Inc, Kent, United Kingdom), which connected the laryngeal mask and the

From the Department of Thoracic Surgery and Medicine, Kamaishi Municipal Hospital, Iwate, Japan.

Received for publication April 15, 2002; accepted for publication June 5, 2002.

Address for reprints: Shinichiro Okada, MD, Department of Thoracic Surgery and Medicine, Kamaishi Municipal Hospital, 3-15-26, Ohwataricho, Kamaishi, Iwate, 026-0025 Japan (E-mail: shin575@opal. famille.ne.jp).

J Thorac Cardiovasc Surg 2002;124:1032-4

Copyright $\odot 2002$ by The American Association for Thoracic Surgery

$0022-5223 / 2002 \$ 35.00+0 \quad \mathbf{1 2 / 5 4 / 1 2 7 0 0 5}$

doi: $10.1067 / \mathrm{mtc} .2002 .127005$
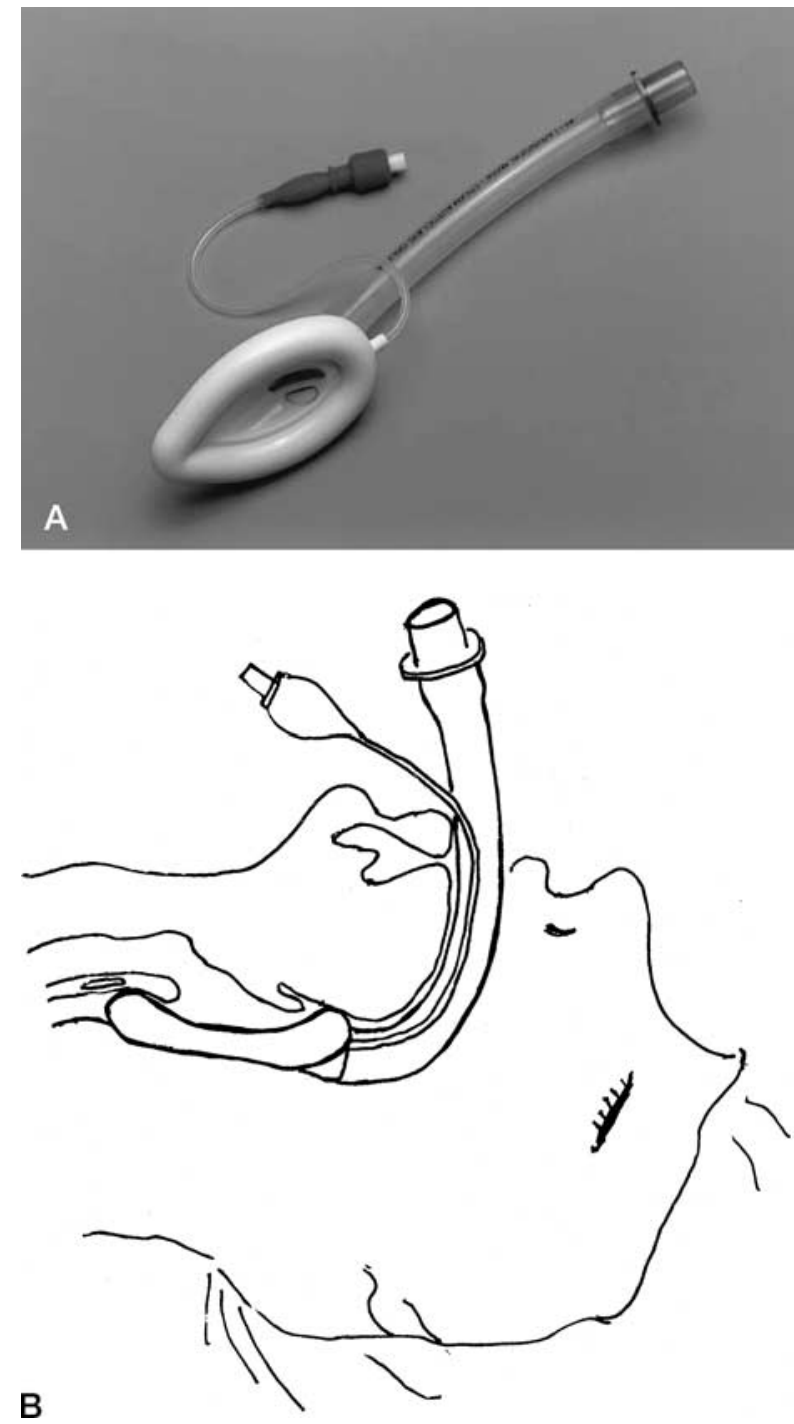

Figure 1. A, A laryngeal mask airway. B, Placement of the laryngeal mask. The deflated cuff of the laryngeal mask is introduced into the hypopharynx with air to seal off the glottis.

anesthesia machine. A guide wire through the working channel of the flexible bronchoscope was introduced beyond the stenotic site. After the bronchoscope was removed, a thin, fiberoptic flexible bronchoscope (BF3C30; Olympus) was passed through the cap of the slit of the swivel connector. The stent loader was also passed through the slit of the laryngeal mask, and it was introduced into 
TABLE 1. Patients' characteristics and outcomes

\begin{tabular}{|c|c|c|c|c|c|c|c|c|c|c|}
\hline $\begin{array}{l}\text { Patient no. } \\
\text { (age [y], sex) }\end{array}$ & $\begin{array}{c}\text { Disease } \\
\text { (histology) }\end{array}$ & Site & $\begin{array}{l}\text { Signs and } \\
\text { symptoms }\end{array}$ & Stenosis & $\begin{array}{l}\text { Laryngeal } \\
\text { mask } \\
\text { size }\end{array}$ & $\begin{array}{l}\text { Operation } \\
\text { time (min) }\end{array}$ & $\begin{array}{l}\text { Combined } \\
\text { therapy }\end{array}$ & Result & Complication & Current status \\
\hline $1(64, F)$ & $\begin{array}{l}\text { Thyroid tumor } \\
\text { (adeno) }\end{array}$ & UT & $\begin{array}{l}\text { Dyspnea, } \\
\text { Cough }\end{array}$ & $95 \%$ & 3 & 20 & APC & Satisfactory & None & 27 mo, alive \\
\hline $2(48, M)$ & $\begin{array}{r}\text { Lung cancer } \\
\text { (adenoma) }\end{array}$ & RMB & $\begin{array}{l}\text { Dyspnea, } \\
\text { Cough }\end{array}$ & $90 \%$ & 4 & 14 & APC & Satisfactory & None & $3 \mathrm{mo}$, dead \\
\hline $3(58, F)$ & $\begin{array}{l}\text { Thyroid cancer } \\
\text { (papillary adeno) }\end{array}$ & UT & $\begin{array}{l}\text { Bloody } \\
\text { sputum, } \\
\text { Stridor }\end{array}$ & $85 \%$ & 3 & 26 & APC & Satisfactory & None & 25 mo, alive \\
\hline $4(62, F)$ & $\begin{array}{l}\text { Thyroid cancer } \\
\text { (papillary adeno) }\end{array}$ & UT & $\begin{array}{l}\text { Dyspnea, } \\
\text { Stridor }\end{array}$ & $95 \%$ & 3 & 15 & APC & Satisfactory & None & 3 mo, alive \\
\hline $5(87, F)$ & $\begin{array}{l}\text { Thyroid cancer } \\
\text { (papillary adeno) }\end{array}$ & UT & $\begin{array}{l}\text { Bloody } \\
\text { sputum, } \\
\text { Stridor }\end{array}$ & $90 \%$ & 3 & 18 & APC & Satisfactory & None & 37 mo, alive \\
\hline $6(78, F)$ & $\begin{array}{l}\text { Lung cancer (small } \\
\text { cell ca) }\end{array}$ & LMB & $\begin{array}{l}\text { Dyspnea, } \\
\text { Stridor }\end{array}$ & $85 \%$ & 3 & 22 & None & Satisfactory & None & $2 \mathrm{mo}$, dead \\
\hline $7(78, F)$ & $\begin{array}{l}\text { Lung cancer } \\
\text { (adeno) }\end{array}$ & RMB & $\begin{array}{l}\text { Dyspnea, } \\
\text { Stridor }\end{array}$ & $90 \%$ & 3 & 25 & None & Satisfactory & None & $18 \mathrm{mo}$, dead \\
\hline $8(80, F)$ & $\begin{array}{l}\text { Lung cancer } \\
\text { (adeno) }\end{array}$ & LMB & $\begin{array}{l}\text { Dyspnea, } \\
\text { Stridor }\end{array}$ & $95 \%$ & 3 & 22 & None & Satisfactory & None & $1 \mathrm{mo}$, dead \\
\hline $9(67, M)$ & $\begin{array}{l}\text { Lung cancer (small } \\
\text { cell ca) }\end{array}$ & LMB & $\begin{array}{l}\text { Dyspnea, } \\
\text { Bloody } \\
\text { sputum }\end{array}$ & $80 \%$ & 4 & 30 & None & Satisfactory & None & 4 mo, alive \\
\hline $10(79, \mathrm{M})$ & $\begin{array}{l}\text { Lung cancer } \\
\text { (squamous cell } \\
\text { ca) }\end{array}$ & TI & $\begin{array}{l}\text { Dyspnea, } \\
\text { Cough }\end{array}$ & $100 \%$ & 4 & 17 & APC & Satisfactory & None & $1 \mathrm{mo}$, dead \\
\hline $11(72, \mathrm{M})$ & $\begin{array}{l}\text { Lung cancer } \\
\text { (adeno) }\end{array}$ & RMB & $\begin{array}{l}\text { Dyspnea, } \\
\text { bloody } \\
\text { sputum }\end{array}$ & $90 \%$ & 4 & 22 & $\begin{array}{l}\text { Electro- } \\
\text { cautery }\end{array}$ & Satisfactory & None & 5 mo, dead \\
\hline $12(78, M)$ & $\begin{array}{l}\text { Lung cancer } \\
\text { (squamous cell } \\
\text { ca) }\end{array}$ & LMB & $\begin{array}{l}\text { Dyspnea, } \\
\text { bloody } \\
\text { sputum }\end{array}$ & $90 \%$ & 4 & 23 & $\begin{array}{l}\text { Electro- } \\
\text { cautery }\end{array}$ & Satisfactory & None & $2 \mathrm{mo}$, dead \\
\hline
\end{tabular}

Adeno, Adenocarcinoma; UT, upper trachea; $A P C$, Argon plasma coagulation; RMB, right main bronchus; $C a$, carcinoma; $L M B$, left main bronchus; $T$, Truncus Intermedius bronchus.

the laryngeal mask tube and trachea. Then the expandable metallic stent that was passed through the stent loader was pushed out to sit across the stenosis under bronchoscopic vision. When subsequent fiberoptic bronchoscopy indicated the need to move the stent, it was precisely moved into the correct location with the use of a biopsy forceps. The entire procedure was performed without interruption of ventilation during the procedure. Percutaneous oxygen saturation with a pulse oximeter, blood pressure measurement, and electrocardiographic results were monitored during the procedure. Results were considered satisfactory when airway dilation at the stenotic site or improved clinical symptoms or both were achieved. Any outcome that did not accomplish the aims was judged unsatisfactory.

\section{Results and Discussion}

Patients' characteristics and results are summarized in Table 1. Between April 1996 and December 2001, 12 patients aged 48 to 87 years (mean, 71 years) received tracheobronchial stent treatment. The patients included 5 men and 7 women, having 1 benign tumor, 3 thyroid cancers, and 8 primary lung cancers.
Stent placement was successful in all patients. The stenotic or obstructive site was successfully dilated in all patients, and in 7 patients having symptoms, such as dyspnea, stridor, and cough, the symptoms were relieved immediately after the operation. Before the stent placement, 5 patients received argon plasma coagulation for reduction of the tumor and dilation of the airway stenosis or obstruction. In 1 (patient 4 ) of 4 patients with thyroid cancer, an emergency argon plasma coagulation for the endotracheal tumor, causing pinhole stenosis of the subglottic trachea, was performed. Thereafter, a self-expandable metallic stent was placed. The patient's symptoms, such as dyspnea and stridor, were relieved promptly. In 1 patient (patient 1) with a benign thyroid tumor presenting stridor and shortness of breath, an urgent surgical intervention for the progressively deteriorating retinal detachment was indicated. Thereafter, urgent endotracheal stenting under a flexible bronchoscope and laryngeal mask placement at the stenosed site of the upper trachea was performed, and subsequently, the surgical retinal reattachment was followed by mild sore throat postoperatively, which spontaneously resolved. 
The operating time ranged from 14 to 30 minutes (mean, 21 minutes). No complications, either related or unrelated to the procedure, occurred in any of the patients. No deaths have occurred from stent failure or related complications. Percutaneous oxygen saturation, blood pressure, and electrocardiographic results were not changed during the procedure. The delivery of the selfexpandable metallic stent within the airway by using the laryngeal mask was easy and quick, without interrupting ventilation in all patients. Also, positioning of the stent under the direct bronchoscopic vision was easy and exact, without need of fluoroscopy. Satisfactory results were achieved in all patients.

Our preliminary results showed that self-expandable metallic stents can be inserted safely, quickly, and exactly with a laryngeal mask and a fiberoptic flexible bronchoscope without the use of fluoroscopy in the treatment of selected tracheobronchial tumors. This new procedure will, however, require careful evaluation in larger series.

The procedure, under general anesthesia, might be considered a disadvantage, but the use of general anesthesia allowed no motion of the patient and steady visualization of the airway during the procedure reduced risky complications and reduced the operating time.

\section{References}

1. Cortese DA. Rigid versus flexible bronchoscope in laser bronchoscopy, prorigid bronchoscopic laser application. J Bronchology. 1994; 1:72-3.

2. Okada S, Ishimori S, Sato M, Satoh S, Sugawara H, Tanaba Y. Endoscopic surgery with use of a laryngeal mask and a fiberoptic flexible bronchoscope. J Thorac Cardiovasc Surg. 2001;121:1196-7.

3. Okada S, Yamauchi H, Ishimori S, Satoh S, Sugawara H, Tanaba Y. Endoscopic surgery with a flexible bronchoscope and argon plasma coagulation for tracheobronchial tumors. J Thorac Cardiovasc Surg. 2001;121:180-2.

4. Joshi GP, Inagaki Y, White PF, et al. Use of the laryngeal mask as an alternative to the tracheal tube during ambulatory anesthesia. Anesth Analg. 1997;85:573-7.

5. Brain AIJ. The laryngeal mask-a new concept in airway management. Br J Anaesth. 1983;55:801-5. 